\title{
MUTYH GIn324His gene polymorphism and genetic susceptibility for lung cancer in a Japanese population
} Aiko Miyaishi ${ }^{1,2}$, Kayo Osawa*1, Yasunori Osawa1 ${ }^{1}$ Natsuko Inoue ${ }^{1}$, Kana Yoshida ${ }^{3}$, Mayumi Kasahara ${ }^{1}$, Akimitsu Tsutou${ }^{1}$, Yoshiki Tabuchi ${ }^{4}$, Kazuo Sakamoto ${ }^{5}$, Noriaki Tsubota ${ }^{6,7}$ and Juro Takahashi ${ }^{1}$

\author{
Address: ${ }^{1}$ Faculty of Health Sciences, Kobe University Graduate School of Medicine, Kobe, Japan, ${ }^{2}$ Clinical Laboratory, Otemae Hospital, Osaka, \\ Japan, ${ }^{3}$ Osaka Cancer Immuno-Chemotherapy Center, Osaka, Japan, ${ }^{4}$ Department of Surgery, Yoshida Ardent Hospital, Kobe, Japan, ${ }^{5}$ Department \\ of Radiology, Joyo Ejiri Hospital, Himeji, Japan, ${ }^{6}$ Department of Thoracic Surgery, Hyogo Medical Center for Adults, Akashi, Japan and \\ ${ }^{7}$ Department of Thoracic Oncology, Hyogo College of Medicine, Nishinomiya, Japan \\ Email: Aiko Miyaishi - m-stone@mtj.biglobe.ne.jp; Kayo Osawa* - osawak@kobe-u.ac.jp; Yasunori Osawa - gcc01325@nifty.com; \\ Natsuko Inoue - natu720@coast.ocn.ne.jp; Kana Yoshida - kanapyon7@hotmail.co.jp; Mayumi Kasahara - mayu-cherry10@ja3.so-net.ne.jp; \\ Akimitsu Tsutou - tsutou@kobe-u.ac.jp; Yoshiki Tabuchi - y-tabuchi@hi-net.zaq.ne.jp; Kazuo Sakamoto - ekus-nnak4040@meg.winknet.ne.jp; \\ Noriaki Tsubota - ntsubo@hm.h555.net; Juro Takahashi - Jtaka-16-taka@S4.dion.ne.jp \\ * Corresponding author
}

Published: 22 January 2009

Journal of Experimental \& Clinical Cancer Research 2009, 28:10 doi:10.1 186/1756-9966-28-10

This article is available from: http://www.jeccr.com/content/28/1//0

(C) 2009 Miyaishi et al; licensee BioMed Central Ltd.

This is an Open Access article distributed under the terms of the Creative Commons Attribution License (http://creativecommons.org/licenses/by/2.0), which permits unrestricted use, distribution, and reproduction in any medium, provided the original work is properly cited.
Received: 14 October 2008

Accepted: 22 January 2009

\begin{abstract}
Background: Genetic polymorphisms of DNA repair enzymes in the base excision repair (BER) pathway, may lead to genetic instability and lung cancer carcinogenesis. We investigated the interactions among the gene polymorphisms in DNA repair genes and lung cancer.

Methods: We analyzed associations among OGGI Ser326Cys and MUTYH Gln324His gene polymorphisms in relation to lung cancer risk using PCR-RFLP. The study involved 108 lung cancer patients and $12 \mathrm{I}$ non-cancer controls divided into non-smokers, smokers according to pack-years smoked in Japanese.

Results: The results showed that the MUTYH His/His genotype compared with Gln/Gln genotype showed an increased risk for lung cancer (adjusted odds ratio [OR] 3.03, confidence interval [95\% $\mathrm{Cl}], \mathrm{I} .3 \mathrm{I}-7.00$, $\mathrm{P}=0.010$ ), whereas there was no significant increase for the $\mathrm{Gln} / \mathrm{His}$ genotype (adjusted OR I.35, $95 \% \mathrm{Cl}$ 0.70-2.6I, $\mathrm{p}=0.376$ ). The MUTYH His/His genotype was at a borderline increased risk for both adenocarcinoma and squamous cell carcinoma (adjusted $\mathrm{OR} 2.50,95 \% \mathrm{Cl} 0.95-6.62, \mathrm{P}=0.065$ for adenocarcinoma; adjusted $\mathrm{OR} 3.20,95 \% \mathrm{Cl} 0.89-\mathrm{II} .49, \mathrm{P}=0.075$ for squamous cell carcinoma, respectively). However, the OGGI Ser/Cys or Cys/Cys genotypes compared with the Ser/Ser genotype did not have significantly increased risk for lung cancer, containing either adenocarcinoma or squamous cell carcinoma. The joint effect of tobacco exposure and the MUTYH His/His genotype compared with the Gln/ Gln genotype showed a significant association with lung cancer risk in smokers, and there was not significantly increased in non-smokers (adjusted OR 3.82, $95 \% \mathrm{Cl} 1.22-12.00, \mathrm{p}=0.022$ for smokers; adjusted OR $2.60,95 \% \mathrm{Cl} 0.60-11.25, \mathrm{p}=0.200$ for non-smokers, respectively). The effect of tobacco exposure and the OGGI Ser326Cys showed also no significant risk for lung cancer.
\end{abstract}

Conclusion: Our findings suggest that the MUTYH Gln324His polymorphism appear to play an important role in modifying the risk for lung cancer in the Japanese population. 


\section{Background}

Lung cancer is a well-known cancer that is caused by carcinogens, such as those in tobacco smoke. Tobacco smoke contains many chemical carcinogens and reactive oxygen species, including polycyclic aromatic hydrocarbons. DNA damage induced by these carcinogens or by endogenous metabolic processes can be converted into gene mutations. Recently, in a hospital-based patient-control study, we reported that genetic polymorphisms of NAT2 and CYP1A2 in metabolic processes contributed to lung cancer susceptibility depending on smoking status in Japanese population [1].

Genetic variation in DNA repair genes are thought to modulate DNA repair capacity and are suggested to be related to cancer risk [2]. The base excision repair (BER) pathway, one of the DNA repair pathways, plays an important role in repairing the DNA damage resulting from chemical alterations of a single base, such as methylated, oxidized, or reduced bases [3]. The most stable product of oxidative DNA damage, 8-oxo-7, 8-dihydro-2'deoxyguanosine (8-oxoG), causes $\mathrm{G}: \mathrm{C} \rightarrow \mathrm{T}: \mathrm{A}$ transversions, because 8-oxoG pairs with adenine as well as cytosine [4]. In human cells, the proteins that repair these mutations are 8-oxo-guanine glycosylase-1 (OGG1), which is involved in direct repair by 8-oxoG DNA glycosylase, and mutY homolog (MUTYH), which is involved in repair of adenine to 8 -oxoG mismatch or that of guanine to 1,2-dihydro-2-oxoadenine (2-OH-A) mismatch due to its glycosylase activity $[5,6]$.

In this study, we focused on OGG1 Ser326Cys (rs1052133) and MUTYH Gln324His (rs3219489). In some patient-control studies, OGG1 Ser326Cys appeared to be associated with an increased risk for lung cancer [79], whereas the findings of this association study have been inconsistent [10]. In MUTYH gene, it was shown that the inherited variants Tyr165Cys and Gly382Asp have been associated with colorectal tumors in Caucasians, not in East Asians including Japanese [11-13]. The other polymorphism, MUTYH Gln324His, have been associated with colorectal tumors in a Japanese population [14,15]. Our recent study found that the MUTYH Gln324His constitutes an increased risk of colorectal cancer [16]. To our knowledge, no previous report has examined the effect of MUTYH Gln324His with a functional partner of OGG1, for lung cancer and the significant role of base excision repair genes for oxidative damage in relation to smoking. We also investigated two gene variants in lung cancer with the histological subtypes of adenocarcinoma and squamous cell carcinoma; smoking act differently in the development of various histologic types of lung cancer [17]. Therefore, we specifically examined whether two gene polymorphisms, OGG1 Ser326Cys and MUTYH
Gln324His play an interactive role in the risk for lung cancer incidence in relation to the histological subtypes and the smoking status.

\section{Materials and methods Study subjects}

The lung cancer patients and controls in this small patient-control study were included in a previous study that investigated the genetic polymorphisms of metabolic enzymes [1]. The 108 lung cancer patients (67 with lung adenocarcinoma, 31 with lung squamous cell carcinoma, and 10 with other carcinomas) were recruited between April 2001 and July 2002 at the Hyogo Medical Center for Adults in Akashi City, Japan. The 121 controls who were selected from outpatients with no current or previous diagnosis of cancer were recruited between November 2002 and March 2003. They suffered mainly from: gastrointestinal disease, hypertension and diabetes. Informed consent was obtained and detailed exposure data on smoking was collected by a personal interview. The study design was approved by the Ethics Review Committee on Genetic and Genomic Research, Kobe University Graduate School of Medicine. Informed consent was obtained from all patients and controls, and all samples were coded after collection of blood and data (questionnaire on smoking habits, etc.). The amount of smoke exposure was calculated as pack-years, the product of the number of years an individual smoked and the average number of cigarettes smoked per day (converted into a standard pack of 20 cigarettes).

\section{Genotyping}

The genomic DNA to be used was isolated for the previous study [1]. The genotype of OGG1 Ser326Cys [7] and MUTYH Gln324His [16] was determined by PCR-RFLP analysis, as described previously.

\section{Statistical analysis}

Statistical analysis was performed with the SPSS software package (version 14.0 for Windows; SPSS Japan Inc., Tokyo, Japan). Hardy-Weinberg equilibrium was tested using the goodness-of-fit Chi-square test to compare the observed genotype frequencies with the expected genotype frequencies among the control subjects. Associations were expressed as odds-ratios (OR) with 95\% confidence interval (95\% CI) and p $<0.05$ was considered statistically significant. Logistic regression analysis was performed to assess the association between each genotype and lung cancer. ORs, which were computed to estimate the association between certain genotypes and lung cancer, were adjusted for age, gender, and smoking habit (number of pack-years smoked). The subjects were divided into two groups according to pack-years smoked: never-smokers (pack-years $=0$ ) and ever-smokers (pack-years $>0)$. 


\section{Results}

We present the characteristics of lung cancer in Table 1, including 108 patients and 121 controls. There was no difference in the gender distribution $(\mathrm{p}=0.491)$ between males (patients, 65.7\%; controls, 61.2\%) and females (patients, 34.3\%; controls, 38.8\%). There was no difference in the average ages $( \pm$ SD) between patients $(65.5 \pm$ 9.4 years $)$ and controls $(67.4 \pm 6.7$ years $)(\mathrm{p}=0.078)$. Non-smokers comprised $29.6 \%$ of patients and $45.5 \%$ of controls and smokers comprised $68.5 \%$ of patients and $49.6 \%$ of controls. There was also no difference in the average pack-years $( \pm$ SD) between patients $(33.8 \pm 31.7)$ and controls $(25.6 \pm 35.1)(\mathrm{p}=0.069)$. Histological types of the patients were: 67 adenocarcinoma (62.0\%), 31 squamous cell carcinoma (28.7\%) and 10 others $(9.3 \%)$.

Genotyping results of OGG1 Ser326Cys and MUTYH Gln324His adjusted for gender, age, and smoking habit along with allele frequencies are shown in Table 2. The allele frequencies of the two gene polymorphisms in controls were consistent with the Hardy-Weinberg equilibrium. The crude and adjusted ORs for the OGG1 Ser/Cys or Cys/Cys genotypes compared with the Ser/Ser genotype were not statistically significant. The crude and adjusted ORs for the MUTYH His/His genotype compared with Gln/ Gln genotype showed a increased risk for lung cancer (crude odds ratio [OR] 3.25, 95\% confidence interval [95\%CI] 1.44-7.36, p = 0.005; adjusted OR 3.03, 95\%CI $1.31-7.00, \mathrm{p}=0.010$, respectively), whereas there was no significant increase for the Gln/His genotype (crude OR 1.39, 95\%CI 0.74-2.62, p = 0.309; adjusted OR 1.35, 95\%CI 0.70-2.61, $\mathrm{p}=0.376$, respectively).

Table 3 summarizes the genotype distribution for lung adenocarcinoma and squamous cell carcinoma, showing the OR adjusted for gender, age, and smoking habits. The crude and adjusted ORs for the OGG1 Ser/Cys or Cys/Cys genotypes compared with the Ser/Ser genotype were not significant for adenocarcinoma and squamous cell carcinoma. The crude ORs for the MUTYH His/His genotype compared with Gln/Gln genotype showed a significant increase for both adenocarcinoma and squamous cell carcinoma (OR 3.04, 95\%CI 1.18-7.82, p = 0.021 for adenocarcinoma; OR 4.11, 95\%CI 1.27-13.33, p = 0.019, respectively). The adjusted ORs for the MUTYH His/His genotype compared with $G \ln / G \ln$ genotype showed a borderline significant for adenocarcinoma and squamous cell carcinoma (OR 2.50, 95\%CI 0.95-6.62, $\mathrm{p}=0.065$ for adenocarcinoma; OR 3.20, 95\%CI 0.89-11.49, $\mathrm{p}=0.075$ for squamous cell carcinoma, respectively). While, there was no significant increase for the MUTYH Gln/His genotype in the histological types.

The ORs for the combined effect of tobacco exposure (pack-years smoked) and the two polymorphisms, adjusted for gender and age, are shown in Table 4 . The crude and adjusted ORs for the OGG1 Ser/Cys or Cys/Cys genotypes compared with the Ser/Ser genotype showed no

Table I: Characteristics of lung cancer case and control subjects

\begin{tabular}{|c|c|c|c|c|c|c|}
\hline & \multirow[b]{2}{*}{ Item } & \multicolumn{2}{|c|}{ Patients } & \multicolumn{2}{|c|}{ Controls } & \multirow[b]{2}{*}{ P-value } \\
\hline & & $\mathrm{n}$ & $\%$ & $\mathrm{n}$ & $\%$ & \\
\hline Number & & 108 & & $|2|$ & & \\
\hline \multicolumn{7}{|l|}{ Gender } \\
\hline & males & 71 & 65.7 & 74 & 61.2 & $0.491^{a}$ \\
\hline & females & 37 & 34.3 & 47 & 38.8 & \\
\hline \multicolumn{7}{|l|}{ Age } \\
\hline & $\sim 64$ & 40 & 37.0 & 50 & 41.3 & \\
\hline & $65 \sim 69$ & 17 & 15.7 & 29 & 24.0 & \\
\hline & $70 \sim 74$ & 30 & 27.8 & 20 & 16.5 & \\
\hline & $75 \sim$ & 19 & 17.6 & 22 & 18.2 & \\
\hline & unknown & 2 & 1.9 & 0 & 0.0 & \\
\hline & Mean \pm S.D. & $65.5 \pm 9.4$ & & $67.4 \pm 6.7$ & & $0.078^{b}$ \\
\hline \multicolumn{7}{|c|}{ Smoking status (Pack-years) } \\
\hline & Never (Pack-years $=0$ ) & 32 & 29.6 & 55 & 45.5 & \\
\hline & Ever (Pack-years > 0$)$ & 74 & 68.5 & 60 & 49.6 & \\
\hline & unknown & 2 & 1.9 & 6 & 5.0 & \\
\hline & Mean \pm S.D. & $33.8 \pm 31.7$ & & $25.6 \pm 35.1$ & & $0.069 \mathrm{~b}$ \\
\hline \multicolumn{7}{|c|}{ Histological type } \\
\hline & adenocarcinoma & 67 & 62.0 & & & \\
\hline & squamous cell carcinoma & 31 & 28.7 & & & \\
\hline & others & 10 & 9.3 & & & \\
\hline
\end{tabular}

a: $\chi^{2}$ analysis

b: Student's T-test 
Table 2: Genotype distribution in lung cancer and Allele frequency

\begin{tabular}{|c|c|c|c|c|c|c|c|c|c|c|c|c|}
\hline \multirow{3}{*}{ Genotype } & & \multirow{2}{*}{\multicolumn{2}{|c|}{$\begin{array}{l}\text { patients } \\
(\mathrm{n}=108)\end{array}$}} & \multirow{2}{*}{\multicolumn{2}{|c|}{$\begin{array}{l}\text { controls } \\
(n=|2|)\end{array}$}} & \multirow{2}{*}{\multicolumn{2}{|c|}{ crude }} & \multirow{2}{*}{\multicolumn{2}{|c|}{ adjusted }} & & \multicolumn{2}{|c|}{ Allele frequency } \\
\hline & & & & & & & & & & & \multirow{2}{*}{$\begin{array}{c}\text { patients } \\
\%\end{array}$} & \multirow{2}{*}{$\begin{array}{c}\text { controls } \\
\%\end{array}$} \\
\hline & & $\mathrm{n}$ & $\%$ & $\mathrm{n}$ & $\%$ & OR (95\%Cl) & P-value & OR $(95 \% C l)^{a}$ & P-value & & & \\
\hline \multicolumn{13}{|l|}{ OGGI } \\
\hline & Ser/Ser & 27 & 25.0 & 39 & 32.2 & 1.00 & & 1.00 & & Ser & 0.505 & 0.546 \\
\hline & Ser/Cys & 55 & 50.9 & 54 & 44.6 & $1.47(0.79-2.73)$ & 0.221 & $1.52(0.80-2.91)$ & 0.204 & Cys & 0.495 & 0.455 \\
\hline & Cys/Cys & 26 & 24.1 & 28 & 23.1 & $1.34(0.65-2.77)$ & 0.427 & $1.47(0.69-3.12)$ & 0.313 & & & \\
\hline \multicolumn{13}{|l|}{ MUTYH } \\
\hline & $\mathrm{G} \ln / \mathrm{G} \ln$ & 22 & 20.3 & 37 & 30.6 & 1.00 & & 1.00 & & Gln & 0.468 & 0.591 \\
\hline & $\mathrm{G} \ln / \mathrm{His}$ & 57 & 52.8 & 69 & 57.0 & $1.39(0.74-2.62)$ & 0.309 & $1.35(0.70-2.61)$ & 0.376 & $\mathrm{His}$ & 0.532 & 0.409 \\
\hline & His/His & 29 & 26.9 & 15 & 12.4 & $3.25(1.44-7.36)$ & 0.005 & $3.03(1.31-7.00)$ & 0.010 & & & \\
\hline
\end{tabular}

a: OR adjusted for gender, age, smoking habit

statistically significant risk in non-smokers and smokers. The crude and adjusted ORs for the MUTYH His/His genotype compared with the Gln/Gln genotype showed a significant association with lung cancer risk in smokers (crude OR 3.50, 95\%CI 1.13-10.83, p = 0.030; adjusted OR 3.82, 95\%CI 1.22-12.00, $\mathrm{p}=0.022$, respectively), and there was not statistically significant in non-smokers (crude OR 3.20, 95\%CI 0.81-12.65, p = 0.097; adjusted OR 2.60, 95\%CI $0.60-11.25, \mathrm{p}=0.200$, respectively). The crude and adjusted ORs for the MUTYH Gln/His genotype compared with the Gln/Gln genotype showed no statistically significant risk in non-smokers and smokers.

\section{Discussion}

Herein, we report that gene polymorphisms, OGG1 Ser326Cys and MUTYH Gln324His, of two DNA repair genes in the BER pathway can modulate lung cancer risk in a small case-control study. Our results indicated that lung cancer risk was found to be 3-fold in individuals with the homozygous His/His genotype of MUTYH Gln324His (95\%CI 1.31-7.00, $\mathrm{p}=0.010$ ), whereas that was not with that of OGG1 Ser326Cys. The MUTYH His/His genotype also show a borderline significant risk for both adenocarcinoma and squamous cell carcinoma. Moreover, a joint effect between tobacco smoking and the MUTYH His/His genotype for the risk of lung cancer was statistically

Table 3: Genotype distribution in relation to histological type in lung cancer

\begin{tabular}{|c|c|c|c|c|c|c|c|c|c|c|c|c|c|c|c|c|}
\hline \multirow[t]{3}{*}{ Genotype } & \multicolumn{8}{|c|}{ Adenocarcinoma } & \multicolumn{8}{|c|}{ Squamous Cell Carcinoma } \\
\hline & \multicolumn{2}{|c|}{$\begin{array}{l}\text { patients } \\
(\mathrm{n}=67)\end{array}$} & \multicolumn{2}{|c|}{$\begin{array}{l}\text { controls } \\
(n=12 I)\end{array}$} & \multicolumn{2}{|c|}{ crude } & \multicolumn{2}{|c|}{ adjusted } & \multicolumn{2}{|c|}{$\begin{array}{l}\text { patients } \\
(n=3 I)\end{array}$} & \multicolumn{2}{|c|}{$\begin{array}{l}\text { controls } \\
(n=12 I)\end{array}$} & \multicolumn{2}{|c|}{ crude } & \multicolumn{2}{|c|}{ adjusted } \\
\hline & $n$ & $\%$ & $\mathrm{n}$ & $\%$ & $\begin{array}{c}\text { OR } \\
(95 \% \mathrm{Cl})^{\mathrm{a}}\end{array}$ & P-value & $\begin{array}{c}\text { OR } \\
(95 \% \mathrm{Cl})^{\mathrm{a}}\end{array}$ & P-value & $\mathrm{n}$ & $\%$ & $\mathrm{n}$ & $\%$ & $\begin{array}{c}\text { OR } \\
(95 \% C l)^{a}\end{array}$ & P-value & $\begin{array}{c}\text { OR } \\
(95 \% C l)^{a}\end{array}$ & P-value \\
\hline \multicolumn{17}{|l|}{ OGGI } \\
\hline Ser/Ser & 17 & 25.4 & 39 & 32.2 & 1.00 & & 1.00 & & 8 & 25.8 & 39 & 32.3 & 1.00 & & 1.00 & \\
\hline Ser/Cys & 33 & 49.2 & 54 & 44.6 & $\begin{array}{c}1.40 \\
(0.69-2.87)\end{array}$ & 0.355 & $\begin{array}{c}1.34 \\
(0.64-2.81)\end{array}$ & 0.439 & 16 & 51.6 & 54 & 44.6 & $\begin{array}{c}1.44 \\
(0.56-3.7 \mathrm{I})\end{array}$ & 0.445 & $\begin{array}{c}1.23 \\
(0.44-3.43)\end{array}$ & 0.695 \\
\hline Cys/Cys & 17 & 25.4 & 28 & 23.1 & $\begin{array}{c}1.39 \\
(0.61-3.19)\end{array}$ & 0.434 & $\begin{array}{c}|.3| \\
(0.56-3.08)\end{array}$ & 0.530 & 7 & 22.6 & 28 & 23.1 & $\begin{array}{c}1.22 \\
(0.40-3.75)\end{array}$ & 0.730 & $\begin{array}{c}\text { I.54 } \\
(0.45-5.23)\end{array}$ & 0.491 \\
\hline MUTYH & & & & & & & & & & & & & & & & \\
\hline Gln/Gln & 13 & 19.4 & 37 & 30.6 & 1.00 & & 1.00 & & 6 & 19.4 & 37 & 30.6 & 1.00 & & 1.00 & \\
\hline $\mathrm{Gln} / \mathrm{His}$ & 38 & 56.7 & 69 & 57.0 & $\begin{array}{c}1.57 \\
(0.74-3.30)\end{array}$ & 0.237 & $\begin{array}{c}1.55 \\
(0.72-3.32)\end{array}$ & 0.263 & 15 & 48.4 & 69 & 57.0 & $\begin{array}{c}\text { I.34 } \\
(0.48-3.75)\end{array}$ & 0.576 & $\begin{array}{c}1.00 \\
(0.33-3.01)\end{array}$ & 0.999 \\
\hline $\mathrm{His} / \mathrm{His}$ & 16 & 23.9 & 15 & 12.4 & $\begin{array}{c}3.04 \\
(1.18-7.82)\end{array}$ & 0.021 & $\begin{array}{c}2.50 \\
(0.95-6.62)\end{array}$ & 0.065 & 10 & 32.3 & 15 & 12.4 & $\begin{array}{c}4.11 \\
(1.27-13.33)\end{array}$ & 0.019 & $\begin{array}{c}3.20 \\
(0.89-11.49)\end{array}$ & 0.075 \\
\hline
\end{tabular}

a: OR adjusted for gender, age, smoking habit 
Table 4: Genotype distribution in relation to smoking status in lung cancer

\begin{tabular}{|c|c|c|c|c|c|c|c|c|c|c|c|c|c|c|c|c|}
\hline \multirow[t]{3}{*}{ Genotype } & \multicolumn{8}{|c|}{$\begin{array}{c}\text { Non-smokers } \\
(\text { Pack-years }=0)\end{array}$} & \multicolumn{8}{|c|}{$\begin{array}{c}\text { Smokers } \\
(\text { Pack-years > 0) }\end{array}$} \\
\hline & \multicolumn{2}{|c|}{$\begin{array}{l}\text { patients } \\
(\mathrm{n}=32)\end{array}$} & \multicolumn{2}{|c|}{$\begin{array}{l}\text { controls } \\
(n=55)\end{array}$} & \multicolumn{2}{|c|}{ crude } & \multicolumn{2}{|c|}{ adjusted } & \multicolumn{2}{|c|}{$\begin{array}{l}\text { patients } \\
(\mathrm{n}=74)\end{array}$} & \multicolumn{2}{|c|}{$\begin{array}{l}\text { controls } \\
(\mathrm{n}=60)\end{array}$} & \multicolumn{2}{|c|}{ crude } & \multicolumn{2}{|c|}{ adjusted } \\
\hline & $\mathrm{n}$ & $\%$ & $\mathrm{n}$ & $\%$ & $\begin{array}{c}\text { OR } \\
(95 \% \mathrm{Cl})^{\mathrm{a}}\end{array}$ & P-value & $\begin{array}{c}\text { OR } \\
(95 \% \mathrm{Cl})^{\mathrm{a}}\end{array}$ & $\mathrm{P}$-value & $\mathrm{n}$ & $\%$ & $\mathrm{n}$ & $\%$ & $\begin{array}{c}\text { OR } \\
(95 \% \mathrm{Cl})^{\mathrm{a}}\end{array}$ & $\mathrm{P}$-value & $\begin{array}{c}\text { OR } \\
(95 \% \mathrm{Cl})^{\mathrm{a}}\end{array}$ & $\mathrm{P}$-value \\
\hline \multicolumn{17}{|l|}{ OGGI } \\
\hline Ser/Ser & 5 & 15.6 & 14 & 25.5 & 1.00 & & 1.00 & & 20 & 27.0 & 23 & 38.3 & 1.00 & & 1.00 & \\
\hline Ser/Cys & 20 & 62.5 & 26 & 47.3 & $\begin{array}{c}2.15 \\
(0.67-6.98)\end{array}$ & 0.201 & $\begin{array}{c}2.49 \\
(0.72-8.57)\end{array}$ & 0.148 & 35 & 47.3 & 25 & 41.7 & $\begin{array}{c}I .6 I \\
(0.73-3.54)\end{array}$ & 0.237 & $\begin{array}{c}1.53 \\
(0.69-3.40)\end{array}$ & 0.292 \\
\hline Cys/Cys & 7 & 21.9 & 15 & 46.9 & $\begin{array}{c}|.3| \\
(0.34-5.09)\end{array}$ & 0.700 & $\begin{array}{c}1.38 \\
(0.34-5.64)\end{array}$ & 0.654 & 19 & 25.7 & 12 & 20.0 & $\begin{array}{c}1.82 \\
(0.71-4.66)\end{array}$ & 0.211 & $\begin{array}{c}|.8| \\
(0.70-4.65)\end{array}$ & 0.219 \\
\hline MUTYH & & & & & & & & & & & & & & & & \\
\hline $\mathrm{Gln} / \mathrm{Gln}$ & 5 & 15.6 & 18 & 32.7 & 1.00 & & 1.00 & & 17 & 23.0 & 17 & 28.3 & 1.00 & & 1.00 & \\
\hline $\mathrm{Gln} / \mathrm{His}$ & 19 & 59.4 & 28 & 50.9 & $\begin{array}{c}2.44 \\
(0.77-7.71)\end{array}$ & 0.128 & $\begin{array}{c}2.06 \\
(0.63-6.76)\end{array}$ & 0.233 & 36 & 48.6 & 37 & 61.7 & $\begin{array}{c}0.97 \\
(0.43-2.20)\end{array}$ & 0.947 & $\begin{array}{c}1.07 \\
(0.47-2.46)\end{array}$ & 0.867 \\
\hline $\mathrm{His} / \mathrm{His}$ & 8 & 25.0 & 9 & 16.4 & $\begin{array}{c}3.20 \\
(0.8 \mathrm{I}-12.65)\end{array}$ & 0.097 & $\begin{array}{c}2.60 \\
(0.60-11.25)\end{array}$ & 0.200 & 21 & 28.4 & 6 & 10.0 & $\begin{array}{c}3.50 \\
(1.13-10.83)\end{array}$ & 0.030 & $\begin{array}{c}3.82 \\
(1.22-12.00)\end{array}$ & 0.022 \\
\hline
\end{tabular}

a: OR adjusted for gender, age

increased in smokers, whereas that was not in non-smokers.

We found that no significant effect was apparent between OGG1 Ser326Cys and lung cancer risk, in combination to smoking status. It has been reported that the OGG1 Cys allele in Japanese patients is associated with an increased risk for lung cancer $[8,9]$. The variant OGG1 is deficient in its catalytic activity, was not stimulated by the AP endonuclease [18]. A recent report has suggested that OGG1 Ser326Cys is not associated with lung cancer by metaanalysis [10]. Therefore, our finding in a Japanese population is consistent with the results from the meta-analysis study.

On the other hand, we found that the MUTYH His/His genotype was significantly associated with increased risk of lung cancer. Previous study has shown that the identified variants of the MUTYH gene, containing Gln324His, were unlikely to predispose significantly to the risk for lung cancer in Caucasians [19]. The discrepancy between this study and ours might reflect the differences in genetic background, carcinogen exposure in different populations or sample sizes. Recent study has reported that the MUTYH enzyme activity in Gln324His polymorphism was only $66 \%$ active from the substrates compared with the wild type [20]. It was reported that the 2-OH-A level compared to repair of adenine opposite 8-oxo-G was increased in human cancerous tissues compared to normal tissues [21]. Therefore, it is also possible that the MUTYH enzyme having 324 His variation may have partially a reduced activity in repair of 2-OH-A opposite gua- nine. This suggested that MUTYH Gln324His might also be associated with risk for lung cancer, related to the decreased MUTYH enzyme activity.

In different histological types of lung cancer, MUTYH His/ His genotype was a significantly borderline association for both adenocarcinoma and squamous cell carcinoma, that suggested a potential interaction between this polymorphism and lung cancer risk regardless these subtypes. Moreover, the result of the joint effect between tobacco smoking and MUTYH His/His genotype for the risk of lung cancer was a significant increase in smokers, whereas that was not in non-smokers. If the sample size had been larger, the result in non-smokers might have been significant. This finding suggested that the effect of MUTYH Gln324His for lung cancer risk is not different between smoking habits.

In conclusion, these results suggest that the MUTYH Gln324His polymorphism appear to play an important role in modifying the risk for lung cancer in the Japanese population. To the best of our knowledge, our study is the first case-control study to evaluate the association between the MUTYH Gln324His and lung cancer risk in Japanese. The MUTYHGln324His polymorphism may be one of useful markers of genetic susceptibility to lung cancer and require further verification as predictive biomarkers in a larger study population.

\section{Competing interests}

The authors declare that they have no competing interests. 


\section{Authors' contributions}

$\mathrm{AM}, \mathrm{KO}$ and JT plan the study made all coordination and was involved in the laboratory processing. YO, NI, KY and MK participated in the study and performed the statistical analysis. AT, YT, KS and NT carried out handling the samples. All authors read and approved the final version of manuscript.

\section{References}

I. Osawa Y, Osawa K, Miyaishi A, Higuchi M, Tsutou A, Matsumura S, Tabuchi Y, Tsubota N, Takahashi J: NAT2 and CYPIA2 polymorphisms and lung cancer risk in relation to smoking status. Asian Pac J Cancer Prev 2007, 8: 103-108.

2. Hung RJ, Hall J, Brennan P, Boffetta P: Genetic polymorphisms in the base excision repair pathway and cancer risk: a HuGE review. Am J Epidemiol 2005, I 62:925-942.

3. Wood RD, Mitchell M, Sgouros J, Lindahl T: Human DNA repair genes. Science 200I, 29 I: I284-I 289.

4. Shibutani S, Takeshita M, Grollman AP: Insertion of specific bases during DNA synthesis past the oxidation-damaged base 8oxodG. Nature 199|, 349:43|-434.

5. Boiteux S, Radicella JP: The human OGGI gene: structure, functions, and its implication in the process of carcinogenesis. Arch Biochem Biophys 2000, 377: I-8.

6. Ohtsubo T, Nishioka K, Imaiso Y, Iwai S, Shimokawa H, Oda H, Fujiwara T, Nakabeppu Y: Identification of human MutY homolog (hMYH) as a repair enzyme for 2-hydroxyadenine in DNA and detection of multiple forms of hMYH located in nuclei and mitochondria. Nucleic Acids Res 2000, 28: I355-1364.

7. Le Marchand L, Donlon T, Lum-Jones A, Seifried A, Wilkens LR: Association of the hOGGI Ser326Cys polymorphism with lung cancer risk. Cancer Epidemiol Biomarkers Prev 2002, II:409-4I2.

8. Kohno T, Kunitoh H, Toyama K, Yamamoto S, Kuchiba A, Saito D, Yanagitani N, Ishihara S, Saito R, Yokota J: Association of the OGGI-Ser326Cys polymorphism with lung adenocarcinoma risk. Cancer Sci 2006, 97:724-728.

9. Li H, Hao X, Zhang W, Wei Q, Chen K: The hOGGI Ser326Cys polymorphism and lung cancer risk: a meta-analysis. Cancer Epidemiol Biomarkers Prev 2008, 17:1739-1745.

10. Kiyohara C, Takayama K, Nakanishi Y: Association of genetic polymorphisms in the base excision repair pathway with lung cancer risk: a meta-analysis. Lung Cancer 2006, 54:267-283.

II. Al-Tassan N, Chmiel NH, Maynard J, Fleming N, Livingston AL, Williams GT, Hodges AK, Davies DR, David SS, Sampson JR, Cheadle JP: Inherited variants of MYH associated with somatic G:C->T:A mutations in colorectal tumors. Nat Genet 2002, 30:227-232.

12. Miyaki M, lijima T, Yamaguchi T, Hishima T, Tamura K, Utsunomiya J, Mori T: Germline mutations of the MYH gene in Japanese patients with multiple colorectal adenomas. Mutat Res 2005, 578:430-433.

13. Kim IJ, Ku JL, Kang HC, Park JH, Yoon KA, Shin Y, Park HW, Jang SG, Lim SK, Han SY, Shin YK, Lee MR, Jeong SY, Shin HR, Lee JS, Kim WH, Park JG: Mutational analysis of OGGI, MYH, MTHI in FAP, HNPCC and sporadic colorectal cancer patients: RI54H OGGI polymorphism is associated with sporadic colorectal cancer patients. Hum Genet 2004, I I 5:498-503.

14. Yanaru-Fujisawa R, Matsumoto T, Ushijima Y, Esaki M, Hirahashi M, Gushima M, Yao T, Nakabeppu Y, lida M: Genomic and functional analyses of MUTYH in Japanese patients with adenomatous polyposis. Clin Genet 2008, 73:545-553.

15. Tao H, Shinmura K, Suzuki M, Kono S, Mibu R, Tanaka M, Kakeji Y, Maehara Y, Okamura T, Ikejiri K, Futami K, Yasunami Y, Maekawa T, Takenaka $\mathrm{K}$, Ichimiya $\mathrm{H}$, Imaizumi $\mathrm{N}$, Sugimura $\mathrm{H}$ : Association between genetic polymorphisms of the base excision repair gene MUTYH and increased colorectal cancer risk in a Japanese population. Cancer Sci 2008, 99:355-360.

16. Kasahara M, Osawa K, Yoshida K, Miyaishi A, Osawa Y, Inoue N, Tsutou A, Tabuchi Y, Tanaka K, Yamamoto M, Shimada E, Takahashi J: Association of MUTYH GIn324His and APEXI Asp I 48Glu with colorectal cancer and smoking in a Japanese population. J Exp Clin Cancer Res 2008, 27:49.
17. Barbone F, Bovenzi M, Cavallieri F, Stanta G: Cigarette smoking and histologic type of lung cancer in men. Chest 1997, I I2(6): I 474-1 479.

18. Paz-Elizur T, Sevilya Z, Leitner-Dagan Y, Elinger D, Roisman LC, Livneh Z: DNA repair of oxidative DNA damage in human carcinogenesis: potential application for cancer risk assessment and prevention. Cancer Lett 2008, 266:60-72.

19. Al-Tassan N, Eisen T, Maynard J, Bridle H, Shah B, Fleischmann C, Sampson JR, Cheadle JP, Houlston RS: Inherited variants in MYH are unlikely to contribute to the risk of lung carcinoma. Hum Genet 2004, I I 4:207-2 I0.

20. Ali M, Kim H, Cleary S, Cupples C, Gallinger S, Bristow R: Characterization of mutant MUTYH proteins associated with familial colorectal cancer. Gastroenterology 2008, 135:499-507.

21. Toyokuni S, Mori T, Dizdaroglu M: DNA base modifications in renal chromatin of wistar rats treated with a renal carcinogen, ferric nitrilotriacetate. Int J Cancer 1994, 57:123-128.
Publish with Bio Med Central and every scientist can read your work free of charge

"BioMed Central will be the most significant development for disseminating the results of biomedical research in our lifetime. "

Sir Paul Nurse, Cancer Research UK

Your research papers will be:

- available free of charge to the entire biomedical community

- peer reviewed and published immediately upon acceptance

- cited in PubMed and archived on PubMed Central

- yours - you keep the copyright

Submit your manuscript here:

http://www.biomedcentral.com/info/publishing_adv.asp
BioMedcentral 